\title{
Association of Polymorphisms in the Promoter Region of NOS2A Gene with Primary Knee Osteoarthritis in the Greek Population
}

Andreas Leonidou ${ }^{1}$, Panagiotis Lepetsos ${ }^{2}$, Eustathios Kenanidis ${ }^{1}$, George Macheras ${ }^{3}$, Maria Tzetis ${ }^{4}$ Michael Potoupnis ${ }^{1}$, Eleftherios Tsiridis ${ }^{1,5}$

1. Orthopaedics and Trauma, Aristotle University Medical School, Thessaloniki, GRC 2. Trauma and Orthopedics, KAT Hospital, Athens, GRC 3. Trauma and Orthopaedics, KAT Hospital, Athens, GRC 4. Medical Genetics, University of Athens Medical School, Athens, GRC 5. Orthopaedics, Aristotle University of Thessaloniki, Thessaloniki, GRC

Corresponding author: Andreas Leonidou, leonidou@doctors.org.uk

\section{Abstract \\ Introduction}

A new emerging role of nitric oxide (NO) in the aetiology of osteoarthritis (OA) has been reported. Inducible NO synthase (iNOS), produced by chondrocytes, is the major source of NO in the osteoarthritic cartilage. The aim of this study is to evaluate the potential association between the -1173C/T (rs9282799), -1026 C/A (rs 2779249) and -954G/C (rs 1800482) single nucleotide polymorphisms (SNPs) in the promoter of the iNOS gene (NOS2A) and the incidence of knee OA in Greek population.

\section{Methods}

Ninety-six patients with primary knee OA were included in the study along with 44 controls. Genotypes were identified using polymerase chain reaction (PCR) and DNA sequencing techniques. Allelic and genotypic frequencies were compared between patients and controls.

\section{Results}

None of the $-1173 \mathrm{C} / \mathrm{T},-1026 \mathrm{C} / \mathrm{A}$ and $-954 \mathrm{G} / \mathrm{C}$ SNPs were detected in the studied population, either in patients or controls. However, another SNP was identified at the site -1056 at the promoter region, where the initial $\mathrm{G}$ allele was substituted by the T allele. Interestingly, the TT genotype was completely absent in controls, but was detected in six patients with a $6.2 \%$ observed frequency. The difference between patients and controls was not statistically significant ( $\mathrm{p}$-value $=0.18$ ). In male OA patients, the observed frequency of the TT genotype was higher $(28.6 \%)$ in comparison to the $0 \%$ of the male controls ( $p$-value $=0.1$ ). The frequency of the $\mathrm{G}$ allele was 0.82 in controls and 0.78 in OA patients ( $\mathrm{p}$-value $=0.53$ ).

\section{Conclusions}

Received 12/04/2019

Review began 12/16/2019 Review ended 01/19/2020 Published 01/27/2020

() Copyright 2020

Leonidou et al. This is an open access article distributed under the terms of the Creative Commons Attribution License CC-BY 30 , which permits unrestricted use, distribution, and reproduction in any medium, provided the original author and source are credited.
The present study demonstrates that the 954G/C, $-1026 \mathrm{C} / \mathrm{A},-1056 \mathrm{G} / \mathrm{T}$ and $-1173 \mathrm{C} / \mathrm{T}$ SNPs of the NOS2A gene are not a risk factor for primary knee OA in Greek population. Moreover, -954G/C, -1026C/A and $1173 \mathrm{C} / \mathrm{T}$ are rare, if not completely absent, in the Greek population. Additional research is mandatory in order to investigate the association of these SNPs with OA in different ethnic populations.

Categories: Genetics, Orthopedics

Keywords: osteoarthritis, nitric oxide, single nucleotide polymorphism

\section{Introduction}

Osteoarthritis (OA) is a chronic degenerative joint condition, characterized by degradation of articular cartilage, synovial inflammation, osteophyte formation and subchondral bone sclerosis [1]. OA is a complex disease, influenced by a plethora of genetic and environmental factors, involving several molecular pathways [2,3]. Recently, nitric oxide (NO) has been reported to have a distinctive role in OA pathogenesis $[4]$.

NO is a free radical produced by a reaction between L-arginine and oxygen, catalyzed by a family of enzymes named nitric oxide synthases (NOS) [5]. The inducible form of NOS (iNOS) is mainly generated by human chondrocytes and produces a sustained and extensive quantity of NO which exerts multiple roles in the articular cartilage: mediation of inflammation, chondrocyte apoptosis, extracellular matrix (ECM) degradation, synovial inflammation and subchondral bone dysfunction $[6,7]$.

The elevated levels of iNOS and NO in arthritic tissues suggest that these tissues are actively generating NO $[8,9]$. On the contrary, the chondrocytes of patients without OA do not express iNOS, while iNOS knockout 
mice do not develop experimental OA, raising the possibility that the regulation of NO production may represent a new approach to the management of primary OA $[7,10]$.

The gene encoding iNOS (NOS2A) is located on chromosome region 17q11.2-1q12, spans $37 \mathrm{~Kb}$ and consists of 26 exons [11]. Three single nucleotide polymorphisms (SNPs) in the promoter region, the $-1173 \mathrm{C} / \mathrm{T}$ (rs9282799), the -1026 C/A (rs2779249) and the -954G/C (rs1800482) are linked to increased iNOS expression, resulting in higher NO production [12]. The purpose of this study is to investigate the potential association between the aforementioned SNPs in the promoter of the NOS2A gene and the incidence of knee $\mathrm{OA}$ in Greek population.

\section{Materials And Methods}

After approval of the hospital's ethics review committee, recruitment of participants for this case-control study took place between March 2015 and October 2016. The patient group included adults, suffering from knee OA, with a radiological score $\geqslant 2$ in the Kellgren and Lawrence scale [13]. Patients were excluded when other causes of knee diseases existed, such as rheumatoid arthritis, post-traumatic arthritis, post-septic arthritis, osteonecrosis, skeletal dysplasia or congenital knee disorders. Control group included patients with no symptoms or clinical signs of OA, with a score $<2$ in the Kellgren and Lawrence scale. Signed informed consent was obtained from all participants.

A total of $5 \mathrm{ml}$ of peripheral blood were collected from each participant and stored into sodium citrate tubes at $-20^{\circ} \mathrm{C}$. DNA was extracted with a DNA extraction kit (QIAamp DNA Blood Midi Kit, QIAGEN Inc., Valencia, CA) according to manufacturer's instructions. The isolated DNA was amplified by polymerase chain reaction (PCR) using the sense primer 5'-TTAACTTGGGAAAGACAAGAAGG-3' and the antisense primer 5'-

TCTGAACTAGTCACTTGAGG-3' following an initial denaturation step at $95^{\circ} \mathrm{C}$ for $5 \mathrm{~min}$ and an amplification of 34 cycles in a three-step reaction that included denaturation at $94^{\circ} \mathrm{C}$ for $30 \mathrm{sec}$, annealing at $58^{\circ} \mathrm{C}$ for 30 sec and extension at $72^{\circ} \mathrm{C}$ for $2 \mathrm{~min}$, with a final extension step at $72^{\circ} \mathrm{C}$ for $10 \mathrm{~min}$. PCR was performed in a total volume of $24 \mu \mathrm{l}(1 \mu \mathrm{l}$ of DNA, $12.5 \mu \mathrm{l}$ HotStart Taq Plus master mix, $9 \mu \mathrm{l} \mathrm{H2O}$, and $1 \mu \mathrm{l}$ of each primer) placed in 96-well PCR plates. The amplified fragments were analysed on the ABI 3500 Genetic Analyser (Applied Biosystems, Foster City, CA) with the use of the BigDye Terminator v3.1 kit (Applied Biosystems). The identification of polymorphic regions was determined with BioEdit software (Tom Hall, Ibis Therapeutics, Carlsbad, CA).

For the comparison of continuous values among cases and controls and among any other subgroups, the student's unpaired t test was used. Categorical variables, such as gender and genotype frequencies, were compared using the chi-square $\left(\mathrm{X}^{2}\right)$ test. A probability p-value less than 0.05 was considered statistically significant. Statistical analysis was performed using the PASW 18 (SPSS release 18.0; SPSS Inc., Chicago, IL).

\section{Results}

The study included 96 patients with primary knee OA and 44 control subjects. Demographics of the studied population are summarized in Table 1 . The genotypic and allelic frequencies of the $-1173 \mathrm{C} / \mathrm{T},-1026 \mathrm{C} / \mathrm{A}$ and $-954 \mathrm{G} / \mathrm{C}$ polymorphisms are summarized in Table 2 . Only the common aforementioned SNPs were identified in the studied population, either in patients or controls, raising the possibility that the minor allele of these SNPs is completely absent in the Greek population. However, another SNP was identified at the site -

$1056 \mathrm{G}>\mathrm{T}$ at the promoter region, where the initial $\mathrm{G}$ allele was substituted by the $\mathrm{T}$ allele. In about the $1 / 3$ of the studied population, the T allele was present. Interestingly, the TT genotype was completely absent in controls, but was detected in six patients with a $6.2 \%$ observed frequency. The difference between patients and controls was not statistically significant $(\mathrm{p}$-value $=0.18$ ). In male OA patients, the observed frequency of the TT genotype was higher $(28.6 \%)$ in comparison to the $0 \%$ of the male controls ( $p$-value $=0.1$ ). The frequency of the $\mathrm{G}$ allele was 0.82 in controls and 0.78 in OA patients ( $\mathrm{p}$-value $=0.53$ ). Figure 1 shows the genotype frequencies of $-1056 \mathrm{G} / \mathrm{T}$ polymorphism in patients and controls. 


\section{Cureus}

\begin{tabular}{|c|c|c|c|c|}
\hline & Controls & Cases & Overall & \\
\hline & $\mathrm{N}(\%)$ & $\mathrm{N}(\%)$ & $\mathrm{N}(\%)$ & $p$-value \\
\hline Gender & & & & 0.062 \\
\hline Female & 32 (72.7) & 82 (85.4) & $114(81.4)$ & \\
\hline Male & $12(27.3)$ & 14 (14.6) & 26 (18.6) & \\
\hline Age (years) & & & & 0.0001 \\
\hline$<71$ & 34 (45.9) & 40 (54.1) & 74 (52.8) & \\
\hline $71<$ & 10 (15.2) & 56 (84.8) & $66(47.2)$ & \\
\hline BMI & & & & 0.0008 \\
\hline$<29$ & $30(50.0)$ & $30(50.0)$ & 60 (47.6) & \\
\hline \multirow[t]{2}{*}{$29<$} & 14 (21.2) & 52 (78.8) & 66 (52.4) & \\
\hline & Mean (SD) & Mean (SD) & Mean (SD) & $p$-value \\
\hline Age (years) & $67.3(10.3)$ & $72.9(9.3)$ & $71.2(9.9)$ & $<0.001$ \\
\hline BMI & $27.5(4.1)$ & $30.6(4.3)$ & $29.5(4.4)$ & $<0.001$ \\
\hline
\end{tabular}

\section{TABLE 1: Descriptive characteristics of the study sample}

BMI: Bone Mass Index; SD: Standard Deviation. 


\section{Cureus}

\begin{tabular}{|c|c|c|c|c|}
\hline & Controls & Cases & Overall & \\
\hline & N (\%) & N (\%) & N (\%) & $\mathrm{p}$-value \\
\hline \multicolumn{5}{|c|}{-954GC polymorphism } \\
\hline GG & $44(100.0)$ & $96(100.0)$ & $140(100.0)$ & 1.000 \\
\hline GC & $0(0.0)$ & $0(0.0)$ & $0(0.0)$ & \\
\hline $\mathrm{CC}$ & $0(0.0)$ & $0(0.0)$ & $0(0.0)$ & \\
\hline G allele frequency & 1.00 & 1.00 & 1.00 & 1.000 \\
\hline $\mathrm{C}$ allele frequency & 0.00 & 0.00 & 0.00 & \\
\hline \multicolumn{5}{|c|}{-1026CA polymorphism } \\
\hline $\mathrm{CC}$ & $44(100.0)$ & $96(100.0)$ & $140(100.0)$ & 1.000 \\
\hline $\mathrm{CA}$ & $0(0.0)$ & $0(0.0)$ & $0(0.0)$ & \\
\hline AA & $0(0.0)$ & $0(0.0)$ & $0(0.0)$ & \\
\hline $\mathrm{C}$ allele frequency & 1.00 & 1.00 & 1.00 & 1.000 \\
\hline A allele frequency & 0.00 & 0.00 & 0.00 & \\
\hline \multicolumn{5}{|c|}{-1056GT polymorphism } \\
\hline GG & $28(63.6)$ & $60(62.5)$ & $88(62.8)$ & 1.000 \\
\hline GT & $16(36.4)$ & 30 (31.3) & $46(32.9)$ & 0.565 \\
\hline TT & $0(0.0)$ & $6(6.2)$ & $6(4.3)$ & 0.177 \\
\hline G allele frequency & 0.82 & 0.78 & 0.79 & 0.528 \\
\hline$T$ allele frequency & 0.18 & 0.22 & 0.21 & \\
\hline \multicolumn{5}{|c|}{ - $11 / 3 \mathrm{C}$ - polymorpnism } \\
\hline CC & $44(100.0)$ & $96(100.0)$ & $140(100.0)$ & 1.000 \\
\hline CT & $0(0.0)$ & $0(0.0)$ & $0(0.0)$ & \\
\hline TT & $0(0.0)$ & $0(0.0)$ & $0(0.0)$ & \\
\hline $\mathrm{C}$ allele frequency & 1.00 & 1.00 & 1.00 & 1.000 \\
\hline T allele frequency & 0.00 & 0.00 & 0.00 & \\
\hline
\end{tabular}

TABLE 2: Genotype and allelic frequencies 




FIGURE 1: Genotype frequencies of -1056GT polymorphism in patients and controls

\section{Discussion}

To the best of our knowledge, this is the first study attempting to assess the role of the polymorphisms of the promoter of the NOS2A gene in the pathogenesis of knee OA. The results of this study suggest that for the $-1173 \mathrm{C} / \mathrm{T},-1026 \mathrm{C} / \mathrm{A}$ and $-954 \mathrm{G} / \mathrm{C}$ polymorphisms, only the major allele is present, in the Greek population. The $-1056 \mathrm{G} / \mathrm{T}$ polymorphism was more common in OA patients, but without statistical significance.

Increased NO release and iNOS expression from osteoarthritic tissues has been widely reported [14]. NO mediates joint inflammation in OA, enhances ECM degradation, decreases ECM production and induces chondrocyte apoptosis [5, 15-17]. In the synovium, NO reduces the survival of OA synoviocytes and induces OA synovial fibroblast apoptosis [18-20].

The presence of SNPs in NOS2A gene has a distinctive role in several conditions affecting different populations. SNPs in the promoter region may influence the level of gene product. iNOS -1173 C/T polymorphism has been correlated with the sickle-cell disease in African populations. The $\mathrm{C}$ to $\mathrm{T}$ change creates a new sequence recognition site for the GATA-1 or GATA-2 transcription factors. The binding of these factors to specific DNA sequences may account for an increased degree of transcription from the -1173 $\mathrm{C}>\mathrm{T}$ promoters [21]. iNOS variant rs $2779249(-1026 \mathrm{C}>\mathrm{A})$ is also located in the promoter region of the gene and it has been shown that nucleotide change from $\mathrm{C}$ to $\mathrm{A}$ increases iNOS promoter transcriptional activity to five-fold leading to higher NO production [22]. This SNP has been associated with hypertension in Chinese Han population and with rheumatoid arthritis in Indians [23,24]. For the $-954 \mathrm{G}>\mathrm{C}$ polymorphism, the substitution of $\mathrm{G}$ to $\mathrm{C}$ results in a phenotype with a seven-fold higher baseline NOS activity [25]. This SNP has been studied in several pathologic conditions, including malaria, diabetes, rheumatoid arthritis, osteomyelitis and asthma [25-29].

In our study, genotyping of $-954 \mathrm{G}>\mathrm{C},-1026 \mathrm{C}>\mathrm{A}$ and $-1173 \mathrm{C}>\mathrm{T}$ in patients with knee $\mathrm{OA}$ and healthy controls revealed the presence of only the major allele of the aforementioned SNPs. Our findings are in agreement with the studies of other Caucasian populations. These SNPs seem to be ethnic-specific for the African population according to previous studies [30]. The $-954 \mathrm{G}>\mathrm{C}$ variation has always been shown to be nonpolymorphic in Caucasian population, all individuals carrying the wild-type $\mathrm{G}$ allele.

Our study revealed that the $-1056 \mathrm{G}>\mathrm{T}$ polymorphism of the NOS2A gene does not affect knee OA susceptibility in the Greek population. The observed lack of association may simply reflect that this SNP has a minor or no role in the onset of knee OA. Another possibility is that the specific polymorphism may contribute to the onset of knee OA, but this influence is too small to be detected with our study size, and a larger sample may be required. The sample size of the present study was not big enough, limiting statistical power for the detection of any existing association.

\section{Conclusions}

Our study indicates that $954 \mathrm{G}>\mathrm{C},-1026 \mathrm{C}>\mathrm{A},-1056 \mathrm{G}>\mathrm{T}$ and $-1173 \mathrm{C}>\mathrm{T}$ of the NOS2A gene are not a risk factor 
for the development of primary knee OA in Greek population. Moreover, for the $-954 \mathrm{G}>\mathrm{C},-1026 \mathrm{C}>\mathrm{A}$ and $1173 \mathrm{C}>\mathrm{T}$ SNPs, the minor allele is rare, if not completely absent, in the Greek population. Additional research is necessary in order to give a global view of these SNPs in the pathogenesis of OA.

\section{Additional Information \\ Disclosures}

Human subjects: Consent was obtained by all participants in this study. Animal subjects: All authors have confirmed that this study did not involve animal subjects or tissue. Conflicts of interest: In compliance with the ICMJE uniform disclosure form, all authors declare the following: Payment/services info: All authors have declared that no financial support was received from any organization for the submitted work. Financial relationships: All authors have declared that they have no financial relationships at present or within the previous three years with any organizations that might have an interest in the submitted work. Other relationships: All authors have declared that there are no other relationships or activities that could appear to have influenced the submitted work.

\section{References}

1. Brandt KD, Dieppe P, Radin EL: Etiopathogenesis of osteoarthritis. Rheum Dis Clin North Am. 2008, 34:531539. 10.1016/j.rdc.2008.05.011

2. Xia B, Chen D, Zhang J, Hu S, Jin H, Tong P: Osteoarthritis pathogenesis: a review of molecular mechanisms. Calcif Tissue Int. 2014, 95:495-505. 10.1007/s00223-014-9917-9

3. Lepetsos P, Pampanos A, Lallos S, Kanavakis E, Korres D, Papavassiliou AG, Efstathopoulos N: Association of NADPH oxidase p22phox gene C242T, A640G and -930A/G polymorphisms with primary knee osteoarthritis in the Greek population. Mol Biol Rep. 2013, 40:5491-5499. 10.1007/s11033-013-2649-5

4. Lepetsos P, Papavassiliou AG: ROS/oxidative stress signaling in osteoarthritis. Biochim Biophys Acta. 2016, 1862:576-591. 10.1016/i.bbadis.2016.01.003

5. Scher JU, Pillinger MH, Abramson SB: Nitric oxide synthases and osteoarthritis. Curr Rheumatol Rep. 2007, 9:9-15. 10.1007/s11926-007-0016-Z

6. Palmer RM, Hickery MS, Charles IG, Moncada S, Bayliss MT: Induction of nitric oxide synthase in human chondrocytes. Biochem Biophys Res Commun. 1993, 193:398-405. 10.1006/bbrc.1993.1637

7. Leonidou A, Lepetsos P, Mintzas M, et al.: Inducible nitric oxide synthase as a target for osteoarthritis treatment. Expert Opin Ther Targets. 2018, 22:299-318. 10.1080/14728222.2018.1448062

8. Amin AR, Di Cesare PE, Vyas P, et al.: The expression and regulation of nitric oxide synthase in human osteoarthritis-affected chondrocytes: evidence for up-regulated neuronal nitric oxide synthase. J Exp Med. 1995, 182:2097-2102. 10.1084/jem.182.6.2097

9. Jang D, Murrell GA: Nitric oxide in arthritis. Free Radical Biol Med. 1998, 24:1511-1519. 10.1016/s08915849(97)00459-0

10. van den Berg WB, van de Loo F, Joosten LA, Arntz OJ: Animal models of arthritis in NOS2-deficient mice . Osteoarthritis Cartilage. 1999, 7:413-415. 10.1053/joca.1999.0228

11. Chartrain NA, Geller DA, Koty PP, et al.: Molecular cloning, structure, and chromosomal localization of the human inducible nitric oxide synthase gene. J Biol Chem. 1994, 269:6765-6772.

12. Qidwai T, Jamal F: Inducible nitric oxide synthase (iNOS) gene polymorphism and disease prevalence . Scand J Immunol. 2010, 72:375-387. 10.1111/j.1365-3083.2010.02458.x

13. Kellgren JH, Lawrence JS: Radiological assessment of osteo-arthrosis. Ann Rheum Dis. 1957, 16:494-502. 10.1136/ard.16.4.494

14. Henrotin Y, Deby-Dupont G, Deby C, De Bruyn M, Lamy M, Franchimont P: Production of active oxygen species by isolated human chondrocytes. Br J Rheumatol. 1993, 32:562-567. 10.1093/rheumatology/32.7.562

15. Henrotin YE, Zheng SX, Deby GP, Labasse AH, Crielaard JM, Reginster JY: Nitric oxide downregulates interleukin 1beta (IL-1beta) stimulated IL-6, IL-8, and prostaglandin E2 production by human chondrocytes. J Rheumatol. 1998, 25:1595-1601.

16. Hauselmann HJ, Stefanovic-Racic M, Michel BA, Evans CH: Differences in nitric oxide production by superficial and deep human articular chondrocytes: implications for proteoglycan turnover in inflammatory joint diseases. J Immunol. 1999, 160:1444-1448.

17. Yudoh K, van Trieu N, Nakamura H, Hongo-Masuko K, Kato T, Nishioka K: Potential involvement of oxidative stress in cartilage senescence and development of osteoarthritis: oxidative stress induces chondrocyte telomere instability and downregulation of chondrocyte function. Arthritis Res Ther. 2005, 7:380-391. 10.1186/ar1499

18. Cillero-Pastor B, Martin MA, Arenas J, Lopez-Armada MJ, Blanco FJ: Effect of nitric oxide on mitochondrial activity of human synovial cells. BMC Musculoskelet Disord. 2011, 12:42. 10.1186/1471-2474-12-42

19. Borderie D, Hilliquin P, Hernvann A, Lemarechal H, Menkes CJ, Ekindjian OG: Apoptosis induced by nitric oxide is associated with nuclear $\mathrm{p} 53$ protein expression in cultured osteoarthritic synoviocytes. Osteoarthritis Cartilage. 1999, 7:203-213. 10.1053/joca.1998.0209

20. Jovanovic DV, Mineau F, Notoya K, Reboul P, Martel-Pelletier J, Pelletier JP: Nitric oxide induced cell death in human osteoarthritic synoviocytes is mediated by tyrosine kinase activation and hydrogen peroxide and/or superoxide formation. J Rheumatol. 2002, 29:2165-2175.

21. Heinemeyer T, Wingender E, Reuter I, et al.: Databases on transcriptional regulation: TRANSFAC, TRRD and COMPEL. Nucleic Acids Res. 1998, 26:362-367. 10.1093/nar/26.1.362

22. Fu L, Zhao Y, Lu J, Shi J, Li C, Liu H, Li Y: Functional single nucleotide polymorphism-1026C/A of inducible nitric oxide synthase gene with increased YY1-binding affinity is associated with hypertension in a Chinese Han population. J Hypertens. 2009, 27:991-1000. 10.1097/hjh.0b013e3283294bec

23. Zhai Z, Wang Z, Wang L, Chen S, Ren H, Wang D: Relationship between inducible NOS single-nucleotide 


\section{Cureus}

polymorphisms and hypertension in Han Chinese. Herz. 2018, 43:461-465. 10.1007/s00059-017-4591-0

24. Negi VS, Mariaselvam CM, Misra DP, et al.: Polymorphisms in the promoter region of iNOS predispose to rheumatoid arthritis in south Indian Tamils. Int J Immunogenet. 2017, 44:114-121. 10.1111/iji.12315

25. Kun JF, Mordmuller B, Lell B, Lehman LG, Luckner D, Kremsner PG: Polymorphism in promoter region of inducible nitric oxide synthase gene and protection against malaria. Lancet. 1998, 351:265-266. 10.1016/S0140-6736(05)78273-8

26. Morris BJ, Markus A, Glenn CL, Adams DJ, Colagiuri S, Wang X: Association of a functional inducible nitric oxide synthase promoter variant with complications in type 2 diabetes. J Mol Med. 2002, 80:96-104. 10.1007/s00109-001-0287-1

27. Gonzalez-Gay MA, Llorca J, Sanchez E, et al.: Inducible but not endothelial nitric oxide synthase polymorphism is associated with susceptibility to rheumatoid arthritis in northwest Spain. Rheumatology. 2004, 43:1182-1185. 10.1093/rheumatology/keh283

28. Canzian F, Franceschi S, Plummer M, et al.: Genetic polymorphisms in mediators of inflammation and gastric precancerous lesions. Eur J Cancer Prev. 2008, 17:178-183. 10.1097/CEJ.0b013e3282b6fd88

29. Holla LI, Stejskalova A, Znojil V, Vasku A: Analysis of the inducible nitric oxide synthase gene polymorphisms in Czech patients with atopic diseases. Clin Exp Allergy. 2006, 36:1592-1601. 10.1111/j.1365-2222.2006.02612.x

30. Johannesen J, Pociot F, Kristiansen OP, Karlsen AE, Nerup J: No evidence for linkage in the promoter region of the inducible nitric oxide synthase gene (NOS2) in a Danish type 1 diabetes population. Genes Immun. 2000, 1:362-366. 10.1038/sj.gene.6363686 